\title{
Children with Sequential Bilateral Cochlear Implants: Effects of Inter-Implant Interval between Implants on Auditory-Verbal Memory Skills in Quiet and Noise
}

\author{
Youngmee Lee \\ Department of Communication Disorders, Tongmyong University, Busan, Korea
}

Correspondence: Youngmee Lee, PhD Department of Communication Disorders, Tongmyong University, 428 Sinseon-ro, Nam-gu, Busan 48520, Korea

Tel: +82-51-629-2135

Fax: +82-51-629-2019

E-mail: ymlee@tu.ac.kr

Received: April 5, 2019

Revised: May 3, 2019

Accepted: May 28, 2019
Objectives: The purpose of this study was to investigate the effects of the inter-implant interval and listening condition on auditory-verbal memory skills in children with sequential bilateral cochlear implants (Cls) and to assess if inter-implant interval between implants would predict their auditory-verbal memory skills in quiet and noise. Methods: Fifteen children with unilateral $\mathrm{Cls}, 15$ children with short range interval between implants (SRI), and 15 children with long range interval between implants (LRI) participated in this study. Children with $\mathrm{Cls}$ received the first $\mathrm{Cl}$ before 3 years of age, and their age at testing ranged from 6 to 13 years. In the auditory-verbal memory tasks, children were asked to immediately repeat the final words of auditorily represented sentences, and then rehearse the words for subsequent recall. Results: All three groups showed significantly better performance on the two tasks in quiet than in noise. Children with SRI recalled significantly more words in noise than children with unilateral Cls and children with LRI did. Auditory-verbal memory skills in noise were significantly correlated with age of the second $\mathrm{Cl}$, duration of the first $\mathrm{Cl}$, and inter-implant interval between implants in children with bilateral $\mathrm{Cls}$. The inter-implant interval between implants was a significant factor predicting auditory-verbal memory skills in noise in children with bilateral Cls. Conclusion: These results suggested that a shorter inter-implant between implants may positively impact on auditory-verbal memory skills in children with bilateral Cls. Inter-implant interval between implants may play a critical role to predict auditory-verbal memory skills in children with bilateral Cls.

Keywords: Children, Bilateral cochlear implants, Inter-implant interval between implants, Listening condition, Auditory-verbal memory 인공와우이식(cochlear implantation)은 양측 고도 이상의 감각 신경성 청각장애인에게 유용한 청력을 제공함으로써 효율적인 재 활방법으로 확고히 자리매김을 하였다(Kim, Jang, Heo, \& Lee, 2007). 일측 인공와우이식(unilateral cochlear implantation)만으 로도 청각장애 아동의 말지각, 말, 언어 발달에 상당히 많은 장점을 제공하지만, 소음 조건에서의 말지각(speech perception)과 소리의 방향 분별(sound localization)에서의 한계를 지니고 있다(Beijen, Snik, \& Mylanus, 2007; Kim et al., 2007; Lee \& Sim, 2015; Nopp, Schleich, \& D'haese, 2004). 이러한 한계를 극복하고자 고도 이상 의 청각장애 성인과 아동을 대상으로 양측 인공와우이식(bilateral cochlear implantation)이 전 세계적으로 활발하게 시행되고 있다 (Peters, Wyss, \& Manrique, 2010).

양측 인공와우이식 아동에 관한 선행연구는 주로 말지각, 소리 방향 분별력, 언어 발달, 청각정보처리 능력(auditory information processing abilities)을 일측과 양측 인공와우이식 집단 간 비교하 거나 시간의 흐름에 따른 양측 인공와우이식 아동의 수행력 변화 에 초점을 맞추어서 분석하였다. 양측 인공와우이식 아동의 말지 각은 일측 인공와우만을 착용했을 때보다는 양측 인공와우를 착 용했을 때에 조용한 조건과 소음 조건에서 모두 말지각이 향상되 었으며, 특히, 소음 조건에서의 말지각은 양측 인공와우 사용기간 
이 길어질수록 점차 향상되며 1 년이 경과한 시점부터는 그 향상이 두드러진다고 보고되고 있다(Kim et al., 2007; Strøm-Roum, Laurent, \& Wie, 2012). 양측 인공와우이식 아동의 소리 방향 분별 정확 도는 양측 인공와우 상태에서 $80 \%-100 \%$, 일측 인공와우만을 착용 한 상태에서는 기회 수준 이하의 저조한 수행력을 보이는 것으로 보고되었다(Beijen et al., 2007; Galvin, Mok, Dowell, \& Briggs, 2008). 양측 인공와우이식 시행 초기와 달리, 최근에는 말지각과 소 리 방향 분별력과 같은 청각 기능을 넘어서는 언어와 청각정보처리 와 관련된 측면에서 양측 인공와우이식 효과를 검증하고자 하는 노력이 진행되고 있다. 선행연구(Boons et al., 2012; Sarant, Harris, Bennet, \& Bant, 2014; Tait et al., 2010)에서는 양측 인공와우이식 아동의 수용 및 표현 어휘 점수가 일측 인공와우이식 아동에 비해 서 유의하게 높으며, 조기에 양측 인공와우이식을 받은 아동일수 록 어휘 점수가 높다고 보고하고 있다. Lee와 Sim (2018)은 양측 인 공와우이식이 듣기 노력(listening effort) 감소에 미치는 직접적인 영향은 적더라도, 청각언어 정보를 처리하는 정확성과 효율성 향 상에 도움이 된다고 보고하였다. 그리고 Jacobs 등(2016)이 양측 인 공와우이식 아동의 구어 추론 능력을 일측 인공와우이식 아동과 비교한 결과에서는 양측 인공와우이식 아동의 구어 추론 능력이 일측 인공와우이식 아동보다 유의하게 높았다. 이러한 결과들은 양측 인공와우이식으로 얻게 된 듣기 능력이 말과 언어 발달을 촉 진하고, 청각정보처리의 효율성을 높이는 데도 도움을 줄수 있음을 시사한다.

본 연구에서는 원활한 청각정보처리에 중요한 청각언어기억(auditory-verbal memory)에 초점을 두어, 양측 인공와우이식 간격이 청각언어기억에 미치는 영향을 살펴보고자 하였다. 청각언어기억 은 청각적으로 제시되는 단어를 포함한 언어정보를 저장하고 회상 할 수 있는 능력이며, 언어, 의사소통, 문해 발달뿐만 아니라 새로운 지식 습득과 매우 관련이 높다(Bellis, 2003). 인공와우이식 아동이 대화, 토론, 담화를 위한 통합적인 듣기 기술을 습득하기 위해서는 다양한 수준의 단어와 문장을 듣고 회상할 수 있는 청각언어기억 의 발달이 필수적이다(Sweetow \& Sabes, 2006). Harris 등(2013)은 인공와우이식 아동의 청각언어기억 점수가 정상청력 아동보다 낮 으며, 청각언어기억은 언어 발달을 예측할 수 있는 변수라고 하였 다. Jang (2012)은 동일한 의미 범주에 속하는 단어를 회상하는 과 제에서 정상적인 언어발달을 보이는 인공와우이식 아동은 정상청 력 아동과 비슷한 수준의 청각언어기억 능력을 가지고 있다고 하였 다. 하지만, 이러한 선행연구들은 일측과 양측 인공와우이식 아동 을 구분하지 않고 실시되었기 때문에, 양측 인공와우이식 아동의 청각언어기억에 대해서 확인하기는 어렵다.
동시적 양측 인공와우이식이 청각장애 아동의 수행력 발달에 미 치는 긍정적인 영향에도 불구하고 일측 인공와우이식에 비해 긴 수술 시간과 더 나은 인공와우이식 기기 발달에 대한 기대로 인해 서, 전체 양측 인공와우이식 아동 중에서 순차적 양측 인공와우이 식(sequential bilateral cochlear implantation)이 동시적 양측 인공 와우이식보다 더 높은 비율을 차지하고 있다(Peters et al., 2010). 이 러한 상황을 고려할 때, 순차적 양측 인공와우이식 아동의 청각언 어기억에 대한 연구를 실시하여, 양측 인공와우이식의 효과를 다 양한 차원에서 검증하고 이를 향상시킬 수 있는 청각재활 프로그 램 개발이 필요하다. 또한, 선행연구(Harris et al., 2013; Jacobs et al., 2016; Jang, 2012)에서 실시한 청각언어기억검사에서는 언어적 맥 락, 말초 청각 수준(peripheral auditory level)에서의 단어재인 실 패, 듣기 환경(예: 소음 조건) 요소에 대한 고려 없이 인공와우이식 아동에게 단어 목록을 들려주고 회상하도록 하여 청각언어기억을 측정하였다. 성공적인 구어 의사소통은 소음 조건에서도 청각과 인지 정보의 처리가 상호의존적이면서 통합적인 과정으로 이루어 진다는 것을 감안할 때(Osman \& Sullivan, 2014), 언어 맥락, 단어 재인, 듣기 조건 등을 고려하여 개발된 청각언어기억검사를 사용 하여 양측 인공와우이식 아동의 실제적인 청각언어기억을 측정할 필요가 있다. 무엇보다 인공와우이식 센터에서는 인공와우이식 아 동의 기능적 듣기 수행력과 삶의 질 향상을 위해서 두 번째 인공와 우이식 연령에 대해서는 제한을 두지 않고 있기 때문에, 순차적 양 측 인공와우이식 아동의 경우, 첫 번째 인공와우이식을 조기에 받 더라도 두 번째 인공와우이식 연령에는 매우 다양한 특징을 보이 고 있다(Kim et al., 2015; Lee, 2018; Peters et al., 2010; Smulders, Rinia, Rovers, van Zanten, \& Grolman, 2011). 이러한 순차적 양측 인공와우이식 아동의 특성을 고려할 때, 조기에 첫 번째 인공와우 이식을 받은 양측 인공와우이식 아동에 한해서 양측 인공와우이식 간격이 청각언어기억에 미치는 영향을 탐색해 볼 필요가 있다. 이에 따라, 본 연구에서는 일측 인공와우이식 아동, 인공와우이식 간격 이 짧은 양측 인공와우이식 아동(children with short range interval between two implants, SRI), 인공와우이식 간격이 긴 양측 인공 와우이식 아동(children with long range interval between two implants, LRI)의 청각언어기억 점수를 조용한 조건과 소음 조건에서 비교하고, 청각언어기억 점수와 양측 인공와우이식 아동의 변수간 의 관련성을 탐색하고, 양측 인공와우이식 간격이 인공와우이식 아 동의 청각언어기억에 영향을 미치는 유의한 변수인지를 살펴보고 자 하였다. 본 연구 목적을 위한 구체적인 연구 질문은 다음과 같다.

첫째, 듣기 조건(조용한 조건, 소음 조건)에 따른 일측 인공와우 이식 아동, 양측 SRI 아동, 양측 LRI 아동의 단어재인 점수에 유의 
한 차이가 있는가?

둘째, 듣기 조건(조용한 조건, 소음 조건)에 따른 일측 인공와우 이식 아동, 양측 SRI 아동, 양측 LRI 아동의 단어회상 점수에 유의 한차이가 있는가?

셋째, 양측 인공와우이식 아동과 관련한 변수와 조용한 조건과 소음 조건에서의 단어회상 점수간에 유의한 상관이 있는가?

넷째, 양측 인공와우이식 간격이 조용한 조건과 소음 조건에서 의 양측 인공와우이식 아동의 단어회상 점수를 예측하는 유의한 변수인가?

\section{연구방법}

\section{연구대상}

본 연구에서는 일측 인공와우이식 아동 15 명과 양측 인공와우 이식 아동 30 명을 대상으로 하였다. 양측 인공와우이식 아동은 양 측 인공와우이식 간격을 기준으로 한 중앙치분리법(median split methods)을 사용하여 양측SRI 아동과 양측LRI 아동으로 구분하 였다. 각 집단의 선정 기준은 다음과 같다. 일측 인공와우이식 아동 은 (1) 선천성 농이며, (2) 인공와우이식을 만 3.5세 이전에 시행받 고, (3) 생활연령이 만 6세에서 13세에 해당되며, (4) 중복장애(예: 지적장애, 자폐스펙트럼장애 등)가 없으며, (5) 구어 의사소통이 원 활한 경우만을 대상으로 하였다. 양측 인공와우이식 아동은 일측 인공와우이식 아동의 선정 기준과 동일하게 대상자를 결정하되, 검사 당시 기준으로 양측 인공와우를 6개월 이상 착용한 경우만을 대상으로 하였다. 일측과 양측 인공와우이식 아동은 모두 인공와 우를 착용한 교정청력(aided threshold)이 500, 1,000, 2,000, 4,000
$\mathrm{Hz}$ 주파수에서 모두 25-35 dB HL에 해당하였다. 집단별 대상자의 생활연령, 인공와우이식 연령, 인공와우 사용기간, 보기가 없는 조 건에서의 단음절단어검사의 음소 점수, 수용어휘 점수에 대한 기 술통계 결과는 Table 1에 제시하였다.

\section{연구과제}

본 연구에서 사용한 청각언어기억검사는 Pichora-Fuller, Schneider와 Daneman (1995)이 성인의 청각언어기억을 측정하기 위해서 개발한 검사를 기초하여 개발하였다. 해당 검사는 들려주는 문장 의 마지막 단어를 즉각적으로 따라 말하는 단어재인 과제(word recognition task)와 따라 말한 단어를 기억하여 다시 말하는 단어 회상 과제(word recall task)로 구성되어 있다. 영어권에서 제작된 청각언어기억검사를 한국어의 특성을 고려하지 않고 그대로 적용 할 경우, 문장의 마지막에 서술어가 위치하여 대상자는 “-(이)다" 의 형태의 목표단어를 듣고 따라 말하고, 다시 회상하여야 한다. 아 동에게 문장을 듣고 마지막에 위치하는 서술어를 그대로 기억하고 회상하도록 할 경우에는 불필요한 저장 부담을 줄 수 있으므로(Ko, Choi, \& Hwang, 2009), 본 검사에서는 인공와우이식 아동의 불필 요한 인지 부담을 줄이고, 기억해야 하는 단어의 연결이 자연스럽 도록 마지막 단어에 명사가 위치할 수 있도록 관형구 형태로 자극 을 개발하였다. 본 연구에서는 단어회상 과제의 점수를 청각언어기 억 수행력으로 간주하였다.

본 검사에서 사용된 관형구는 대상자의 언어 능력의 영향을 최 소화하고자 한국어 문법과 어휘를 통제하였다. 한국어 문법 통제 를 위해서, 자극은 (1) 3어절로 구성하며, (2) 어절당 음절수는 2-5 음절로 제한하였으며, (3) 관계 관형구(예: 전화를 받는 엄마)와 동

Table 1. Participants' characteristics

\begin{tabular}{lccc}
\hline & Unilateral Cl (N=15) & SRI (N=15) & LRI (N=15) \\
\hline Chronological age $(\mathrm{mo})$ & $129.9 \pm 23.7(82-167)$ & $102.8 \pm 23.8(83-153)$ & $159.7 \pm 19.5(129-167)$ \\
Age at implantation (mo) & & & \\
$\quad$ First Cl & $31.1 \pm 7.3(22-41)$ & $30.0 \pm 13.3(19-41)$ & $32.1 \pm 9.8(25-41)$ \\
$\quad$ Second Cl & - & $72.8 \pm 15.7(53-101)$ & $120.3 \pm 16.7(91-144)$ \\
Inter-implant interval between implants (mo) & - & $42.8 \pm 9.3(29-60)$ & $84.2 \pm 14.01(66-111)$ \\
Duration of an implant use (mo) & $98.8 \pm 27.2(40-145)$ & $72.8 \pm 18.8(55-117)$ & $123.6 \pm 16.7(98-139)$ \\
$\quad$ First Cl & - & $30.0 \pm 12.0(16-57)$ & $39.4 \pm 16.7(8-56)$ \\
$\quad$ Second Cl & $83.6 \pm 3.6(80.8-91.5)$ & $90.6 \pm 4.4(80.8-96.9)$ & $84.4 \pm 8.5(69.2-93.8)$ \\
Phoneme scores of MWT (\%) & $108.6 \pm 30.3(52-158)$ & $79.6 \pm 13.9(61-104)$ & $130.3 \pm 33.6(74-167)$ \\
Raw scores of the REVT-R & &
\end{tabular}

Values are presented as mean $\pm \mathrm{SD}$ (range).

$\mathrm{Cl}=$ cochlear implant; Unilateral $\mathrm{Cl}=$ children with unilateral cochlear implants; $\mathrm{SRI}=$ children with short range interval between two implants; $L R I=$ children with long range interval between two implants; MWT= monosyllabic word test (Lee, Shin, Kim, \& Kim, 2009); REVT-R=Receptive and Expressive Vocabulary Test-Receptive (Kim, Hong, Kim, Jang, \& Lee, 2009). 
격 관형구(예: 낮에 뜨는 태양)만으로 제한하였다. 어휘 통제를 위 해서, (1) Kim (2003)과 Cho (2000)가 제시한 고빈도 어휘만으로 선 정하였으며, (2) 아동에게 의미적으로 모호함을 줄 수 있는 은유적, 비유적 표현과 관련된 어휘는 제외하였다. 이러한 기준에 따라서, 총 80 개의 관형구를 제작하였으며, 관형구의 적절성을 확인하기 위 하여 언어치료 경험이 5 년 이상인 언어재활사 1 급 소지자 5 명을 대 상으로 5 점의 Likert 척도 $(1$ 점 $=$ 매우 적절하지 않음, 2 점 $=$ 적절하 지 않음, 3 점 $=$ 보통, 4 점 $=$ 적절함, 5 점 $=$ 매우 적절함 를 사용하여 타당도를 점검하였다. 그리고 검사에 사용한 관형구의 적절성을 확 인하기 위하여, 조용한 조건에서 생활연령이 만 5 세에 해당하는 정 상청력 아동 2 명에게 청각언어기억검사를 실시하여, 대상 아동 모 두 $100 \%$ 의 반응을 보이는 문항만을 선정하였다. 그리고 개발한 검 사에 대한 신뢰도를 확인하기 위하여 Cronbach $\alpha$ 로 측정한 결과, 문항 내적일치도가 .81로 나타났다(범위: .605-.943). 이러한 점검을 통해, 적절하지 않은 관형구는 제거하거나 수정하였으며, 최종적으 로 총 65 개의 관형구로 연습 문항 1 개 세트와 본 문항 12 개 세트를 구성하였다. 각 세트에는 5 개의 관형구를 배치하였으며, 각 세트의 목표단어에는 2음절어를 3개, 3음절어를 2개 배치하였다(Appendix 1). 본 문항 세트는 조용한 조건과 소음 조건에 각각 6개씩 배치 하였으며, 자극 제시의 순서 효과를 배제하기 위해서 제시 순서는 교차균형화(counter-balancing)하였다.

\section{연구절차}

청각언어기억검사는 방음실(SA-1200 single wall; SonTek, Paju, Korea)에서 개별 아동에게 실시하였다. 청력검사기기(GSI 61, Grason-Stadler Inc., Eden Prairie, MN, USA)에 디지털 레코더를 연결 하여 대상 아동의 정면 스피커(방위각 $0^{\circ}$ )를 통해서 $65 \mathrm{~dB} \mathrm{SPL}$ 의 강도로 자극을 제시하였다. 조용한 조건에서는 배경 소음이 40 $\mathrm{dBA}$ 가 넘지 않는 상태에서 음성 자극이 제시되었으며, 소음 조건 에서는 다화자 잡음(multi-talker babble)을 $+8 \mathrm{~dB}$ 의 신호대잡음비 (signal-to-noise ratio, SNR)로 조정된 음성 자극을 제시하였다. 해 당 $\mathrm{SNR}$ 은 소음 조건에서 아동의 청취 능력을 확인하는 데 적절한 $\mathrm{SNR}$ 이 $+8 \mathrm{~dB}$ 라고 보고한 선행연구(Choi, Lotto, Lewis, Hoover, \& Stelmachowicz, 2008; Wackym, Runge-Samuelson, Firszt, Alkaf, \& Burg, 2007)를 토대로 결정하였다. 방음실에서 대상 아동이 인공 와우를 착용한 상태에서 연습 문항을 실시하여, 검사 절차를 충분 히 숙지하고 검사 환경을 편안하게 조정할 수 있도록 하였다. 이때, 연구자는 아동에게 “선생님이 문장을 들려줄 거에요. 그러면 $\mathrm{OO}$ 이가 잘 듣고 문장의 마지막 단어를 따라 말하세요. $\mathrm{OO}$ 이가 말한 단어를 기억했다가, 선생님이 기억한 단어를 모두 말해달라고 하
면, 순서에 상관없이 말하면 돼요."라고 지시하고 아동이 관형구를 듣고 마지막 단어를 따라 말하도록 하였으며, 아동이 마지막 단어 를 따라 말하지 못 했을 때는 연구자가 마지막 단어를 직접 가르쳐 주었다. 그리고 연구자가 아동에게 기억한 단어를 말하도록 요구하 였을 때, 과제를 정확하게 이해하지 못 하거나 오답을 말했을 경우 에는 무엇을 기억해야 하는지를 분명히 알려주었다. 대상 아동이 연습 문항을 통해서 검사 실시 방법을 숙지한 것을 확인한 후에 실 험 문항을 실시하였으며, 실험 문항에서는 아동에게 어떠한 피드백 도 제공하지 않았다.

\section{채점 및 자료 분석}

청각언어기억검사의 채점은 단어재인 과제에서는 아동이 관형 구의 마지막 단어를 따라 말한 단어가 목표어와 일치하면 정반응 $(1$ 점), 불일치하면 오반응(0점)으로 채점하였으며, 단어회상 과제에 서는 관형구 5 개로 구성된 한 세트를 듣고 제시된 순서에 상관없이 마지막에 회상한 단어가 목표단어 목록과 일치하면 정반응(1점), 불일치하면 오반응(0점)으로 채점하였다. 청각언어기억검사의 점 수 산출은 단어재인 과제에서는 아동이 따라 말해야 할 전체 목표 단어수에서 정확하게 따라 말한 단어수를 백분율(\%)로 산출하였 으며, 단어회상 과제에서는 아동이 회상해야 하는 전체 단어수에 서 정확하게 회상한 단어수를 백분율(\%)로 산출하였다. 각 과제의 점수는 듣기 조건에 따라서 대상 아동별로 각각 산출하였다.

\section{자료의 통계적 처리}

첫째, 집단과 듣기 조건에 따른 단어재인 점수와 단어회상 점수에 유의한 차이가 있는지 살펴보기 위해서 이원혼합분산분석(twoway mixed ANOVA)을 각각 실시하였다. 둘째, 듣기 조건별로 양측 인공와우이식 아동의 단어회상 점수와 아동 관련 변수와의 상관 을 살펴보기 위해서, 피어슨 적률상관계수(Pearson correlation coefficient)를 산출하여 분석하였다. 마지막으로, 듣기 조건별로 양측 인공와우이식 아동의 단어회상 점수를 예측할 수 있는 유의한 변 수를 살펴보기 위해서, 단순회귀분석(simple regression analysis) 을 각각 실시하였다. 본 연구에서는 IBM SPSS Statistics version 24 (IBM Co., Armonk, NY, USA)를 사용하여 통계분석을 실시하였 으며, 유의수준은 .05 미만으로 설정하였다.

\section{연구결과}

\section{집단과 듣기 조건에 따른 단어재인 점수 비교}

듣기 조건에 따른 일측 인공와우이식 아동, 양측 SRI 아동, 양측 
Table 2. Word recognition scores in three groups as a function of listening condition

\begin{tabular}{lccc}
\hline Condition & $\begin{array}{c}\text { Unilateral } \mathrm{Cl} \\
(\mathrm{N}=15)\end{array}$ & $\begin{array}{c}\mathrm{SRl} \\
(\mathrm{N}=15)\end{array}$ & $\begin{array}{c}\text { LRI } \\
(\mathrm{N}=15)\end{array}$ \\
\hline Ouiet & $83.67 \pm 16.74$ & $93.33 \pm 6.45$ & $84.00 \pm 14.29$ \\
Noise & $21.67 \pm 13.45$ & $43.33 \pm 18.48$ & $26.00 \pm 15.38$ \\
\hline
\end{tabular}

Values are presented as mean $\pm S D$.

Unilateral $\mathrm{Cl}=$ children with unilateral cochlear implants; $\mathrm{SRI}=$ children with short range interval between two implants; $\mathrm{LRI}=$ children with long range interval between two implants.

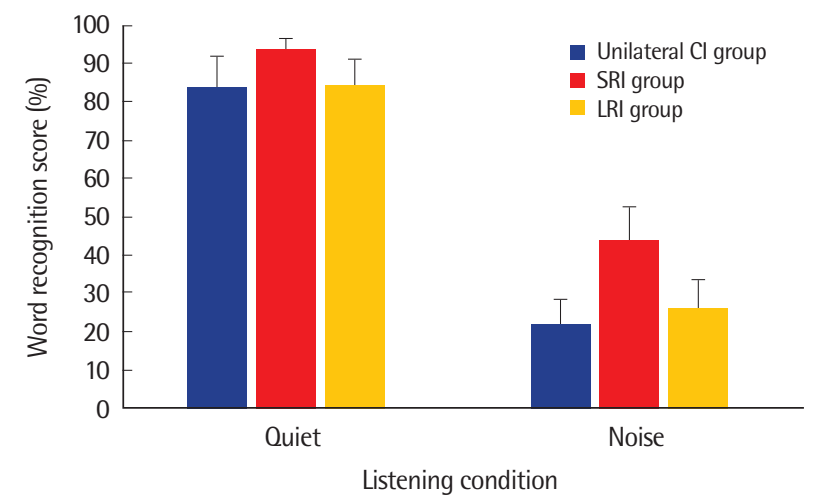

Figure 1. Word recognition scores in quiet and noise for children with unilateral $\mathrm{Cls}$, SRI, and $\mathrm{LRI}$ as a function of listening condition.

$\mathrm{Cl}=$ cochlear implants; $\mathrm{SRI}=$ short range interval between implants; $\mathrm{LRI}=$ long range interval between implants.

LRI 아동의 단어재인 점수에 대한 기술통계 결과는 Table 2에 제시 하였다.

단어재인 점수에 대한 이원혼합분산분석을 실시한 결과, 집단에 대한 주효과가 유의하였다 $\left(F_{(1,42)}=935.741, p<.001, \operatorname{partial} \eta^{2}=.957\right)$. 집단 간 주효과에 대해 Bonferroni 사후검정을 실시한 결과, 일측 인공와우이식 아동, 양측 SRI 아동, 양측 LRI 아동 간에 모두 유의 한 점수 차이가 있었다. 듣기 조건에 주효과도 유의하게 나타나서, 조용한 조건에서의 단어재인 점수가 소음 조건에서보다 유의하게 높았다 $\left(F_{(1,42)}=741.932, p<.001, \operatorname{partial} \eta^{2}=.946\right)$. 집단과 듣기 조 건에 대한 주효과가 유의하여, 듣기 조건별 집단 간 차이를 살펴보 기 위해서 일원배치분산분석을 추가적으로 실시한 결과, 조용한 조건에서의 단어재인 점수는 집단 간에 유의한 차이가 없었으나 $\left(F_{(2,44)}=2.575, p>.05\right)$, 소음 조건에서의 단어재인 점수는 집단 간 에 유의한 차이가 있었다 $\left(F_{(2,44)}=7.793, p<.01\right)$. 이에 따라 Bonferroni 사후검정을 실시한 결과, 일측 인공와우이식 아동과 양측 SRI 아동 $(p<.01)$, 양측 SRI 아동과 양측 LRI 아동 $(p<.05)$ 간에 유의 한 차이가 있었다. 즉, 소음 조건에서는 양측 SRI 아동의 단어재인 점수가 일측 인공와우이식 아동과 양측 LRI 아동에 비해서 유의하
Table 3. Word recall scores in three groups as a function of listening condition

\begin{tabular}{lccc}
\hline Condition & $\begin{array}{c}\text { Unilateral } \mathrm{Cl} \\
(\mathrm{N}=15)\end{array}$ & $\begin{array}{c}\text { SRI } \\
(\mathrm{N}=15)\end{array}$ & $\begin{array}{c}\text { LRI } \\
(\mathrm{N}=15)\end{array}$ \\
\hline Quiet & $51.00 \pm 15.02$ & $53.67 \pm 13.81$ & $58.33 \pm 19.43$ \\
Noise & $23.33 \pm 11.59$ & $34.67 \pm 8.96$ & $22.00 \pm 13.21$ \\
\hline
\end{tabular}

Values are presented as mean $\pm \mathrm{SD}$.

Unilateral $\mathrm{Cl}=$ children with unilateral cochlear implants; SRI=children with short range interval between two implants; $L R=$ children with long range interval between two implants.

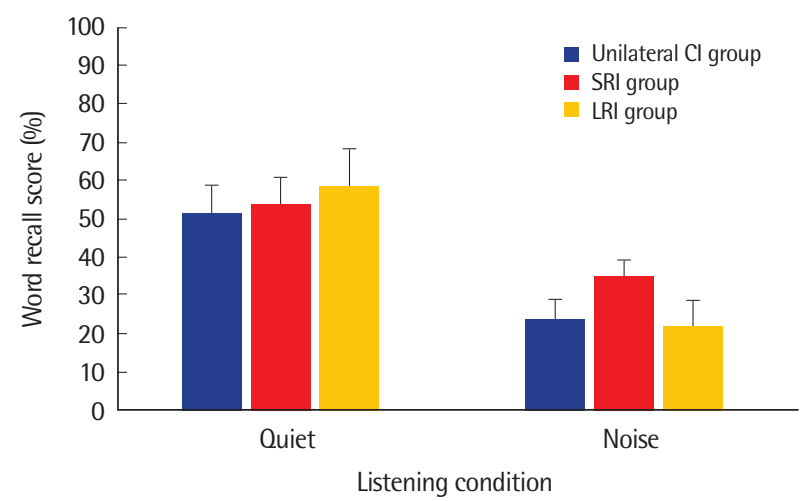

Figure 2. Word recall scores in quiet and noise for children with unilateral Cls, SRI, and LRI as a function of listening condition.

$\mathrm{Cl}=$ cochlear implants; $\mathrm{SRI}=$ short range interval between implants; $\mathrm{LRI}=$ long range interval between implants.

게 높았다. 집단과 듣기 조건에 대한 이차 상호작용은 유의하지 않 았다 $\left(F_{(2,42)}=2.875, p>.05\right.$, partial $\left.\eta^{2}=.120\right)$ (Figure 1).

\section{집단과 듣기 조건에 따른 단어회상 점수 비교}

듣기 조건에 따른 일측 인공와우이식 아동, 양측 SRI 아동, 양측 LRI 아동의 단어재인 점수에 대한 기술통계 결과는 Table 3에 제시 하였다.

단어회상 점수에 대한 이원혼합분산분석을 실시한 결과, 집단 에 대한 주효과는 유의하지 않았다 $\left(F_{(2,42)}=1.171, p>.05\right.$, partial $\left.\eta^{2}=.053\right)$. 듣기 조건에 대한 주효과는 유의하여, 조용한 조건에서 의 단어회상 점수가 소음 조건에서보다 유의하게 높았다 $\left(F_{(1,42)}=\right.$ 219.973, $p<.001$, partial $\eta^{2}=.840$ ). 집단과 듣기 조건에 대한 이차 상호작용효과는 유의하게 나타났다 $\left(F_{(2,42)}=7.195, p<.01\right.$, partial $\left.\eta^{2}=.255\right)$. 이에 대한 사후검정으로 LMATRIX와 MMATRIX 명령 어를 사용하여 대비검정을 실시하였다. 그 결과, 일측 인공와우이 식 아동과 양측 SRI 아동 $(p<.001)$, 양측 LRI 아동과 양측 SRI 아 동 $(p<.001)$ 간의 단어회상 점수 차이가 조용한 조건에 비해서 소 음 조건에서 유의하게 컸다. 즉, 일측 인공와우이식 아동과 양측 
Table 4. Correlation coefficients among child variables and word recognition scores in quiet and noise for children with bilateral $\mathrm{Cls}(\mathrm{N}=30)$

\begin{tabular}{|c|c|c|c|c|c|c|c|c|}
\hline & $\begin{array}{l}\text { Chronological } \\
\text { age }\end{array}$ & $\begin{array}{l}\text { Age of the } \\
\text { first } \mathrm{Cl}\end{array}$ & $\begin{array}{l}\text { Age of the } \\
\text { second } \mathrm{Cl}\end{array}$ & $\begin{array}{l}\text { Inter-implant } \\
\text { interval be- } \\
\text { tween implants }\end{array}$ & $\begin{array}{l}\text { Duration of the } \\
\text { first implant } \\
\text { use }\end{array}$ & $\begin{array}{l}\text { Duration of the } \\
\text { second implant } \\
\text { use }\end{array}$ & $\begin{array}{l}\text { Receptive vo- } \\
\text { cabulary scores }\end{array}$ & $\begin{array}{c}\text { Word recall } \\
\text { scores in quiet }\end{array}$ \\
\hline Chronological age & - & & & & & & & \\
\hline Age of the first $\mathrm{Cl}$ & $.584^{* *}$ & - & & & & & & \\
\hline Age of the second $\mathrm{Cl}$ & $.916^{* *}$ & $603^{* * *}$ & - & & & & & \\
\hline Inter-implant interval between implants & $.839 * * *$ & $.856^{* * *}$ & $.932^{* * *}$ & - & & & & \\
\hline Duration of the first implant use & $.961^{* * *}$ & .317 & $.856^{* * *}$ & $.880^{* * *}$ & - & & & \\
\hline Duration of the second implant use & $.672^{* * *}$ & .256 & .317 & .262 & $689^{* * *}$ & - & & \\
\hline Receptive vocabulary scores & $.751^{* * *}$ & $.473^{* *}$ & $.602^{* * *}$ & $.510^{* *}$ & $.709^{* * *}$ & $.663^{* * *}$ & - & \\
\hline Word recall scores in quiet & .111 & .264 & .070 & -.036 & .038 & .181 & $.426^{*}$ & - \\
\hline Word recall scores in noise & $-.403^{*}$ & -.200 & $-.474^{* *}$ & $-.480^{* *}$ & $-.399 *$ & -.078 & -.256 & $.547^{* *}$ \\
\hline
\end{tabular}

$\mathrm{Cl}=$ cochlear implant.

${ }^{*} p<.05,{ }^{* *} p<.01,{ }^{* * *} p<.001$.

Table 5. Results of simple regression analysis

\begin{tabular}{cccccc}
\hline & $\mathrm{B}$ & $\beta$ & $R^{2}$ & $t$ & $p$-value \\
\hline Inter-implant between implants & -.265 & -.480 & .231 & -2.898 & .007 \\
\hline
\end{tabular}

LRI 아동의 단어회상 점수가 조용한 조건에 비해서 소음 조건에서 양측 SRI 아동에 비해 유의하게 떨어졌다(Figure 2).

\section{양측 인공와우이식 아동 변수과 단어회상 점수와의 상관관계}

양측 인공와우이식 아동과 관련된 변수(생활연령, 첫 번째와 두 번째 인공와우이식 연령, 첫 번째와 두 번째 인공와우 사용기간, 인 공와우이식 간격, 수용어휘 점수), 조용한 조건과 소음 조건에서의 단어회상 점수간의 상관분석 결과는 Table 4에 제시하였다.

조용한 조건에서의 양측 인공와우이식 아동의 단어회상 점수는 수용어휘 점수 $(r=.426, p<.05)$, 소음 조건에서의 단어회상 점수 $(r=.547, p<.01)$ 와 유의한 상관을 보였으며, 소음 조건에서의 단어 회상 점수는 생활연령 $(r=-.403, p<.05)$, 두 번째 인공와우이식 연 령 $(r=-.474, p<.01)$, 인공와우이식 간격 $(r=-.480, p<.01)$, 첫 번째 인공와우 사용기간 $(r=-.399, p<.05)$ 과 유의한 상관을 보였다(Table 4).

\section{양측 인공와우이식 간격이 인공와우이식 아동의 단어회상 점수에 미치는 영향}

양측 인공와우이식 아동의 인공와우이식 간격을 독립변수로, 단 어회상 점수를 종속변수로 하여 단순회귀분석을 듣기 조건별로 각 각 실시하였다. 조용한 조건에서의 단어회상 점수를 종속변수로 회 귀분석을 실시한 결과, 양측 인공와우이식 간격은 조용한 조건에 서의 단어회상 점수를 유의하게 예측하는 변수는 아니었다 $(\beta=$
-.026, $p>$ >05). 소음 조건에서의 단어회상 점수를 종속변수로 회귀 분석을 실시한 결과에서는 양측 인공와우이식 간격이 인공와우이 식 아동의 단어회상 점수를 예측하는 유의한 변수였다 $(\beta=-.480$, $p<.01)$. 양측 인공와우이식 간격은 인공와우이식 아동의 소음 조 건에서의 단어회상 점수에 대해 총 $23.1 \%$ (수정계수에 의하면 20.3\%) 의 설명력을 보였다(Table 5).

\section{논의 및 결론}

본 연구에서는 일측 인공와우이식 아동, 양측 SRI 아동, 양측 LRI 아동 모두 조용한 조건에서의 단어재인과 단어회상 능력이 소음 조건에 비해서 높았으며, 소음 조건에서는 양측 SRI 아동의 단어재 인과 단어회상 능력이 다른 두 집단에 비해서 높았다. 양측 인공와 우이식 간격은 소음 조건에서의 단어회상 능력과 상관이 있었으며, 이러한 결과는 회귀분석 결과를 통해서도 확인하였다.

본 연구에서는 일측 인공와우이식 아동, 양측 SRI 아동, 양측 LRI 아동 모두 조용한 조건에서의 단어재인 점수가 소음 조건보다 유의하게 높았다(Table 2). 이는 소음이 단어재인에 부정적인 영향 을 미친다는 선행연구(Crandell, 1993; Jamieson, Kranjc, Yu, \& Hodgetts, 2004; Kim et al., 2007; Lee \& Sim, 2015; Strøm-Roum et al., 2012) 결과와 일치한다. Crandell (1993)은 경도 청각장애 아동 과 정상청력 아동의 문장재인 점수를 조용한 조건과 소음 조건에 서 비교한 결과, 두 집단 모두 소음 조건에서 문장재인 점수가 조용 한 조건에 비해 저하되었다. Jamieson 등(2004)은 정상청력 아동이 더라도 연령이 어릴 경우에는 청소년이나 성인에 비해 소음 조건에 서 단어를 많이 놓쳐서, 소음 조건에서의 대화 참여와 학습에서 겪 는 어려움이 크다고 언급하였다. 이러한 결과는 소음이 청자의 말 
초청각수준(peripheral auditory level)에서 불필요한 음향 정보를 추가하거나 필요한 음향 정보를 차폐시켜, 중추청각수준(central auditory level)에서 단어를 정확하게 재인하는 것을 방해를 하기 때문인 것으로 생각된다. 그리고 집단에 따른 단어재인 점수를 살 펴보면, 양측 SRI 아동, 양측 LRI 아동, 일측 인공와우이식 아동의 순서로 점수가 높았다(Table 2). 이러한 결과는 인공와우이식 아동 의 조용한 조건에서의 말지각 점수와 관련이 있을 것으로 생각된 다. 본 연구에서 양측 SRI 아동의 보기가 없는 조건에서의 단음절 단어검사의 음소 점수가 일측 인공와우이식 아동과 양측 LRI 아동 에 비해서 유의하게 높았다. 이러한 결과는 양측 인공와우이식 아 동 중에서 인공와우이식 간격이 짧은 아동이 긴 아동에 비해서 더 나은 단어재인 능력을 성취할 수 있기 때문에(Gordon \& Papsin, 2009; Lee, 2014), 양측 인공와우이식 효과를 극대화하기 위해서는 조기에 양측 인공와우이식을 동시적으로 시행하거나 인공와우이 식 간격을 최대한 짧게 시행할 필요성이 높다는 것을 의미한다. 또 한, 본 연구에서는 인공와우이식 간격이 긴 양측 인공와우이식 아 동이 일측 인공와우이식 아동에 비해 더 나은 단어재인 능력을 성 취하였으며, 이는 늦은 두 번째 인공와우이식도 말지각에 긍정적인 영향을 미칠 수 있다는 것을 시사한다(Kim et al., 2007; Lee \& Sim, 2015; Strøm-Roum et al., 2012).

일측 인공와우이식 아동, 양측 SRI 아동, 양측 LRI 아동 모두 조 용한 조건에서의 단어회상 점수가 소음 조건에서보다 유의하게 높 았다(Table 3). Osman과 Sullivan (2014)이 문장 판단하기와 문장 의 마지막 단어회상하기 과제로 구성된 청각언어기억검사를 조용 한 조건과 소음 조건에서 정상청력 아동에게 실시한 결과에서도 조 용한 조건에서의 문장판단하기와 단어회상 점수 모두 소음 조건보 다 높았다. 본 연구에서 주목할 점은 단어회상 점수에 대한 집단 간 에 유의한 차이는 없었지만, 집단과 듣기 조건에 따른 이차 상호작 용효과가 유의하였다는 것이다. 이차 상호작용효과는 일측 인공와 우이식 아동과 양측 LRI 아동의 단어회상 점수가 조용한 조건보다 소음 조건에서 양측 SRI 아동에 비해 많이 떨어진 것에 기인한 것으 로, 결국 양측 SRI 아동이 일측 인공와우이식 아동과 양측 LRI 아 동에 비해서 소음 조건에서 더 나은 단어회상 점수를 성취하여서 나타난 결과로 해석할 수 있다. 본 연구에 참여한 양측 SRI 아동의 생활연령과 수용어휘 점수는 일측 인공와우이식 아동과 양측 LRI 아동보다 낮았기 때문에, 양측 SRI 아동의 경우, 관형구의 청취, 단 어재인, 단어회상의 전 과정에 다른 집단에 비해서 유리하다고 볼 수 없다. 그럼에도 불구하고, 양측 SRI 아동의 단어회상 점수가 다 른 집단에 비해서 높은 결과에 대해서는 이들의 단어재인 능력과 듣기 노력 측면에서 설명해 볼 수 있다. 첫째, 본 연구에 참여한 양측
SRI 아동의 단어재인 점수가 소음 조건에서 일측 인공와우이식 아 동과 양측 LRI 아동보다 높았기 때문에, 재인한 단어를 기억하는 단어회상 과제의 특성상 양측 SRI 아동이 다른 두 집단의 아동보다 단어회상에서 유리했을 것이다. 둘째, 소음 조건에서 더 나은 단어 재인 능력을 지닌 양측 SRI 아동의 경우, 일측 인공와우이식 아동 과 양측 LRI 아동에 비해 듣기 노력이 적게 소요되어, 더 많은 단어 를 회상할 수 있었을 것이다. Pichora-Fuller 등(1995)은 청자의 제 한된 인지 용량(limited cognitive capacity)으로 인해 단어재인과 같은 듣기 활동에 집중과 인지 자원을 많이 사용하게 되면, 듣기와 동시에 진행하는 다른 인지 활동에 필요한 집중과 인지 자원이 줄 어들어서 수행력이 감소된다고 하였다. 이러한 제한인지용량 모델 을 근거로 할 때, 일측 인공와우이식 아동과 양측 LRI 아동이 소음 조건에서 단어재인에 많은 인지 자원을 활용하여, 단어회상하기에 서 양측SRI 아동보다 더 적은 단어를 회상했을 수도 있다.

본 연구에서는 조용한 조건에서 양측 인공와우이식 아동의 단 어회상 점수는 수용어휘 점수와 유의한 상관을 보였다(Table 4). 즉, 양측 인공와우이식 아동의 단어회상 점수가 높을수록 수용어 휘 점수도 높았다. Kronenberger 등(2013)은 인공와우이식 아동의 청각언어기억 능력이 어휘 발달과 관련성이 높다고 보고하면서, 청 각언어기억이 높은 인공와우이식 아동이 청각언어기억이 낮은 인 공와우이식 아동에 비해서 어휘 발달 속도가 빠르다고 하였다. Harris 등(2013)도 인공와우이식 아동의 청각언어기억과 어휘 발 달과의 관련성에 대해서 언급하면서, 인공와우이식 아동의 청각언 어기억을 증진시킬 수 있는 청능재활 프로그램 개발을 통해 보다 나은 언어 능력을 성취할 수 있도록 해야 한다고 강조한 바 있다. 이 러한 결과는 인공와우이식 아동에게 청각언어기억 발달의 지연 혹 은 결함이 있을 시에 원활한 언어 발달이 어려울 수 있으며, 인공와 우이식 아동의 청각언어기억 능력이 언어 발달에서의 개인 간 차이 를 설명하는 변수가 될 수 있음을 의미한다(Harris et al., 2013; Pisoni, 2000).

소음 조건에서는 양측 인공와우이식 아동의 단어회상 점수가 생 활연령, 두 번째 인공와우이식 연령, 인공와우이식 간격, 첫 번째 인 공와우 사용기간과 유의한 상관을 보였다. 양측 인공와우이식 아 동의 연령이 어리고 첫 번째 인공와우 사용기간이 짧을수록 단어 회상 점수가 높은 것으로 나타났는데, 이에 대한 해석은 주의를 기 울일 필요가 있다. 본 연구에 참여한 양측 인공와우이식 아동 중에 서, 인공와우이식 간격이 짧은 SRI 아동이 LRI 아동에 비해서 연령 이 어리며 첫 번째 인공와우 사용기간이 짧은 경향이 있었다. 양측 SRI 아동이 소음 조건에서의 단어회상 과제에서 양측 LRI 아동보 다 높은 수행력을 보였기 때문에, 생활연령과 첫 번째 인공와우 사 
용기간이 단어회상 점수와 부적 상관을 보였을 것으로 생각된다. 그러므로 본 결과에 대해서는 첫 번째 인공와우이식을 조기에 받 고 두 번째 인공와우이식 연령이 다양한 양측 인공와우이식 집단 으로 제한하여 해석할 필요가 있다. 그리고 소음 조건에서 두 번째 인공와우이식 연령이 어리고 인공와우이식 간격이 짧을수록 양측 인공와우이식 아동의 단어회상 점수가 높게 나타났다. 이러한 결 과는 순차적 양측 인공와우이식 아동의 수행력 발달을 극대화하 기 위해서는 인공와우이식 간격을 짧게 하여 양측 인공와우이식을 모두 조기에 받는 것이 중요하다고 한 선행연구(Gordon \& Papsin, 2009; Lee, 2014; Smulders et al., 2011)의 결과를 지지하는 것으로, 두 번째 인공와우이식 연령과 인공와우이식 간격이 말지각, 말, 언 어 발달 외에도 청각언어기억과도 관련이 있다는 것을 의미한다.

본 연구에서는 회귀분석 결과를 통해서도 인공와우이식 간격이 양측 인공와우이식 아동의 소음 조건에서의 단어회상 점수를 유 의하게 예측하는 변수라는 것을 확인하였다. 이러한 결과는 조기 에 첫 번째 인공와우이식을 받은 경우에는 인공와우이식 간격을 짧게 하는 것이 양측 인공와우이식 아동이 다양한 듣기 환경에서 더 나은 청각언어기억 능력을 성취할 수 있도록 도움을 준다는 것 을 의미한다. Lammers, Venekamp, Grolman과 van der Heijden (2014)은 인공와우이식 간격이 길어지면 양측 인공와우이식 아동 이 얻을 수 있는 양이청 이득이 줄어들어서 말지각, 말, 언어 발달에 서의 이득이 인공와우이식 간격이 짧은 아동보다 떨어진다고 하였 다. Jacobs 등(2016)은 동시적 양측 인공와우이식을 받은 아동의 언 어지능이 일측 인공와우이식 아동보다 높다는 것을 언급하면서, 소음 조건에서의 말지각, 청각언어기억, 언어지능 간에 관련성이 있 다고 하였다. 즉, 동시적 혹은 조기에 양측 인공와우이식을 받아서 인공와우이식 간격을 짧게 하는 것이 궁극적으로 청각장애 아동 의 양측 청성 뇌가소성(auditory-brain plasticity) 발달을 유리하게 하여(Gordon, Valero, \& Papsin, 2007), 양측 인공와우이식 아동의 전반적인 수행력 발달에 긍정적인 효과를 미치는 것이다.

본 연구에서는 일측 인공와우이식 아동, 양측 SRI 아동, 양측 LRI 아동의 단어재인과 단어회상 점수가 듣기 조건에 따라 유의한 차이가 났으며, 세 집단 모두 소음 조건보다는 조용한 조건에서 더 나은 수행력을 보였다. 특히, 소음 조건에서의 단어회상 과제에서 는 양측 SRI 아동의 점수가 일측 인공와우이식 아동과 양측 LRI 아동보다 유의하게 높게 나타나서, 인공와우이식 간격이 짧은 양측 인공와우이식 아동이 소음 조건에서 더 많은 단어를 회상할 수 있 다는 것을 확인하였다. 그리고 양측 인공와우이식 아동의 단어회 상 점수가 조용한 조건에서는 수용어휘 점수와 유의한 상관이 있 었으며, 소음 조건에서는 생활연령, 두 번째 인공와우이식 연령, 인
공와우이식 간격, 첫 번째 인공와우 사용기간과 유의한 상관이 있 었다. 이는 듣기 조건에 따라서 양측 인공와우이식 아동의 청각언 어기억과 관련 있는 변수가 달라질 수 있음을 의미한다. 두 번째 인 공와우이식 연령이 어리고 인공와우이식 간격이 짧을수록, 소음 조건에서 양측 인공와우이식 아동의 청각언어기억 능력이 우수하 였다. 그리고 인공와우이식 간격이 소음 조건에서의 양측 인공와우 이식 아동의 단어회상 점수를 유의하게 예측하는 변수로 나타나 서, 인공와우이식 간격이 양측 인공와우이식 아동의 청각언어기억 능력의 개인 간 차이를 설명할 수 있는 변수임을 확인하였다. 그러 므로 순차적 양측 인공와우이식을 시행하는 아동의 경우, 양측 인 공와우이식을 짧은 간격으로 시행받아 더 나은 청각언어기억 능력 을 성취할 수 있도록 해야 할 것이다. 나아가 다양한 듣기 조건에서 의 청각언어기억 능력을 향상시킬 수 있도록 양측 인공와우이식 아 동을 위한 청능재활 프로그램을 개발하여, 양측 인공와우이식 아 동이 다양한 듣기 조건에서도 청각언어 정보를 기억하고 처리하는 데 도움을 받을 수 있도록 할 필요가 있겠다. 그리고 향후 연구에서 는 이상적인 시기(optimal timing)에 양측 인공와우이식을 시행받 은 대상에게 다양한 형태의 청각언어기억검사를 실시하여, 인공와 우이식 간격이 양측 인공와우이식 아동의 청각정보처리 능력에 미 치는 영향을 살펴볼 필요가 있을 것이다. 또한, 양측 인공와우이식 아동의 청각언어기억 능력을 정상청력 아동과 비교함으로써 양측 인공와우이식의 청각언어기억 능력의 특성을 살펴보고, 양측 인공 와우이식 효과를 다양한 측면에서 확인할 필요가 있을 것이다.

\section{REFERENCES}

Beijen, J. W., Snik, A. F., \& Mylanus, E. A. (2007). Sound localization ability of young children with bilateral cochlear implants. Otology \& Neurotology, 28(4), 479-485.

Bellis, T. J. (2003). Assessment and management of central auditory processing disorders in the educational setting: from science to practice (2nd ed.). Clifton Park, NY: Thomson/Delmar Learning.

Boons, T., Brokx, J. P., Frijns, J. H., Peeraer, L., Philips, B., Vermeulen, A., ... \& Van Wieringen, A. (2012). Effect of pediatric bilateral cochlear implantation on language development. Archives of Pediatrics \& Adolescent Medicine, 166(1), 28-34.

Cho, H. Y. (2000). A study on Korean vocabulary education. Seoul: Pagijong.

Choi, S., Lotto, A., Lewis, D., Hoover, B., \& Stelmachowicz, P. (2008). Attentional modulation of word recognition by children in a dual-task paradigm. Journal of Speech, Language, and Hearing Research, 51(4), 1042-1054. 
Crandell, C. C. (1993). Speech recognition in noise by children with minimal degrees of sensorineural hearing loss. Ear and Hearing, 14(3), 210-216.

Galvin, K. L., Mok, M., Dowell, R. C., \& Briggs, R. J. (2008). Speech detection and localization results and clinical outcomes for children receiving sequential bilateral cochlear implants before four years of age. International Journal of Audiology, 47(10), 636-646.

Gordon, K. A., \& Papsin, B. C. (2009). Benefits of short interimplant delays in children receiving bilateral cochlear implants. Otology \& Neurotology, 30(3), 319-331.

Gordon, K. A., Valero, J., \& Papsin, B. C. (2007). Auditory brainstem activity in children with 9-30 months of bilateral cochlear implant use. Hearing Research, 233(1-2), 97-107.

Harris, M. S., Kronenberger, W. G., Gao, S., Hoen, H. M., Miyamoto, R. T., \& Pisoni, D. B. (2013). Verbal short-term memory development and spoken language outcomes in deaf children with cochlear implants. Ear and Hearing, 34(2), 179-192.

Jacobs, E., Goedegebure, A., Smits, C., Ariens-Meijer, S. A., Mylanus, E. A., \& Vermeulen, A. M. (2016). Benefits of simultaneous bilateral cochlear implantation on verbal reasoning skills in prelingually deaf children. Research in Developmental Disabilities, 58, 104-113.

Jamieson, D. G., Kranjc, G., Yu, K., \& Hodgetts, W. E. (2004). Speech intelligibility of young school-aged children in the presence of real-life classroom noise. Journal of the American Academy of Audiology, 15(7), 508-517.

Jang, S. (2012). Semantic short-term memory according to category knowledge in children with cochlear implants (Master's thesis). Daegue University, Gyeongsan, Korea.

Kim, K. (2003). Vocabularies for different levels of Korean education. Seoul: Pagijong.

Kim, L. S., Jang, Y. S., Heo, S. D., \& Lee, Y. M. (2007). Bilateral cochlear implantation in four children. Korean Journal of Otorhinolaryngology-Head and Neck Surgery, 50(3), 260-264.

Kim, Y. J., Roh, J., Lee, J. J., Hong, S. A., Lim, H. J., Park, H. Y., \& Choung, Y. H. (2015). Functional listening performance of children with sequential bilateral cochlear implantation in daily life. Korean Journal of Otorhinolaryngology-Head and Neck Surgery, 58(7), 463-468.

Kim, Y. T., Hong, G. H., Kim, K. H., Jang, H. S., \& Lee, J. Y. (2009). Receptive and expressive vocabulary test (REVT). Seoul: Seoul Community Rehabilitation Center.

Ko, S., Choi, K. S., \& Hwang, M. (2009). The development of reading span in children. Korean Journal of Communication Disorders, 14(3), 303-312.
Kronenberger, W. G., Pisoni, D. B., Harris, M. S., Hoen, H. M., Xu, H., \& Miyamoto, R. T. (2013). Profiles of verbal working memory growth predict speech and language development in children with cochlear implants. Journal of Speech, Language, and Hearing Research, 56(3), 805-825.

Lammers, M. J., Venekamp, R. P., Grolman, W., \& van der Heijden, G. J. (2014). Bilateral cochlear implantation in children and the impact of the inter-implant interval. The Laryngoscope, 124(4), 993-999.

Lee, M. Y., Shin, J. C., Kim, H. H., \& Kim, L. S. (2009). Open-set monosyllabic speech perception test for preschool children. Korean Journal of Otorhinolaryngology-Head and Neck Surgery, 52(4), 312-321.

Lee, Y. (2014). Effects of the inter-implant interval and listening condition on speech perception in children with sequential bilateral cochlear implants. Communication Sciences \& Disorders, 19(4), 564-573.

Lee, Y. (2018). Functional listening performance of sequential bilateral cochlear implantation in young adults with congenital deafness. Communication Sciences \& Disorders, 23(4), 1111-1126.

Lee, Y., \& Sim, H. S. (2015). Speech perception benefits of bilateral cochlear implantation for deaf children. Journal of Rehabilitation Research, 19(3), 175-193.

Lee, Y., \& Sim, H. S. (2018). The effects of listening conditions on sentence judgement and listening effort in school-aged children with bilateral cochlear implants in a dual-task paradigm. Communication Sciences \& Disorders, 23(3), 764-774.

Nopp, P., Schleich, P., \& D’haese, P. (2004). Sound localization in bilateral users of MED-EL COMBI 40/40+ cochlear implants. Ear and Hearing, 25(3), 205-214.

Osman, H., \& Sullivan, J. R. (2014). Children's auditory working memory performance in degraded listening conditions. Journal of Speech, Language, and Hearing Research, 57(4), 1503-1511.

Peters, B. R., Wyss, J., \& Manrique, M. (2010). Worldwide trends in bilateral cochlear implantation. The Laryngoscope, 120(S2), S17-S44.

Pichora-Fuller, M. K., Schneider, B. A., \& Daneman, M. (1995). How young and old adults listen to and remember speech in noise. The Journal of the Acoustical Society of America, 97(1), 593-608.

Pisoni, D. B. (2000). Cognitive factors and cochlear implants: Some thoughts on perception, learning, and memory in speech perception. Ear and Hearing, 21(1), 70-78.

Sarant, J., Harris, D., Bennet, L., \& Bant, S. (2014). Bilateral versus unilateral cochlear implants in children: a study of spoken language outcomes. Ear and Hearing, 35(4), 396-409. 
Smulders, Y. E., Rinia, A. B., Rovers, M. M., van Zanten, G. A., \& Grolman, W. (2011). What is the effect of time between sequential cochlear implantations on hearing in adults and children? A systematic review of the literature. The Laryngoscope, 121(9), 1942-1949.

Strøm-Roum, H., Laurent, C., \& Wie, O. B. (2012). Comparison of bilateral and unilateral cochlear implants in children with sequential surgery. International Journal of Pediatric Otorhinolaryngology, 76(1), 95-99.

Sweetow, R. W., \& Sabes, J. H. (2006). The need for and development of an adaptive listening and communication enhancement (LACE program).
Journal of the American Academy of Audiology, 17(8), 538-558.

Tait, M., Nikolopoulos, T. P., De Raeve, L., Johnson, S., Datta, G., Karltorp, E., ... \& Gulpen, P. M. H. (2010). Bilateral versus unilateral cochlear implantation in young children. International Journal of Pediatric Otorhinolaryngology, 74(2), 206-211.

Wackym, P. A., Runge-Samuelson, C. L., Firszt, J. B., Alkaf, F. M., \& Burg, L. S. (2007). More challenging speech perception tasks demonstrate binaural benefit in bilateral cochlear implant users. Ear \& Hearing, 28(2), 80S-85S. 
Youngmee Lee • Auditory Memory Skills for Children with Bilateral CIs

Appendix 1. 청각언어기억 과제에 사용된 관형구 예시

\begin{tabular}{lclc}
\hline & 번호 & \multicolumn{1}{c}{ 관형구 } & 목표단어 \\
\hline Practice & 1 & 코가 긴 코끼리 & 코끼리 \\
& 2 & 책을 읽는 학생 & 학생 \\
& 3 & 철도를 달리는 기차 & 기차 \\
& 4 & 여자가 입는 치마 & 치마 \\
Set 1 & 5 & 하늘을 나는 독수리 & 독수리 \\
& 1 & 시끄럽게 우는 아기 & 아기 \\
& 2 & 돈이 많은 부자 & 부자 \\
& 3 & 머리를 자르는 미용사 & 미용사 \\
& 4 & 어린이가 보는 만화 & 만화 \\
Set 2 & 5 & 원숭이가 좋아하는 바나나 & 바나나 \\
& 1 & 모양이 둥근 수박 & 수박 \\
& 2 & 요리사가 만든 음식 & 음식 \\
& 3 & 맛이 짠 소금 & 소금 \\
& 4 & 불을 끄는 소방관 & 소방관 \\
& 5 & 색깔이 빨간 토마토 & 토마토 \\
\hline & & &
\end{tabular}




\section{국문초록}

\section{인공와우이식 간격과 듣기 조건이 양측 인공와우이식 아동의 청각언어기억 능력에 미치는 영향 이영미}

동명대학교 언어치료학과

배경 및 목적: 본 연구에서는 인공와우이식 간격과 듣기 조건에 따른 양측 인공와우이식 아동의 청각언어기억 능력을 살펴보고, 양측 인공와우이식 아동 관련 변수와 청각언어기억 능력과의 관련성을 탐색하고자 하였다. 방법: 본 연구는 학령기의 일측 인공와우이식 아 동 15 명과 양측 인공와우이식 아동 30 명을 대상으로 하였으며, 양측 인공와우이식 아동은 중앙치반분법에 따라서 인공와우이식 간격 이 짧은 아동 15 명과 인공와우이식 간격이 긴 아동 15 명으로 구분하였다. 문장 내 단어재인 과제와 단어회상 과제로 구성된 청각언어기 억검사를 아동에게 개별적으로 조용한 조건과 소음 조건으로 방음실에서 실시하였다. 결과: 모든 집단에서 조용한 조건에서 단어재인 과 단어회상 과제의 점수가 소음 조건보다 유의하게 높았다. 인공와우이식 간격이 짧은 아동이 일측 인공와우이식 아동과 인공와우이 식 간격이 긴 아동에 비해서 소음 조건에서 유의하게 많은 단어를 기억하여 회상할 수 있다. 회귀분석 결과, 인공와우이식 간격이 양측 인공와우이식 아동의 청각언어기억 능력을 예측할 수 있는 유의한 변수였다. 논의 및 결론: 양측 인공와우이식 간격이 짧은 아동이 긴 아동에 비해서 더 나은 청각언어기억 능력을 보였으며, 양측 인공와우이식 간격이 소음 조건에서의 청각언어기억 능력에 유의한 영향 을 미쳤다. 순차적 양측 인공와우이식의 경우, 첫 번째와 두 번째 인공와우이식을 모두 조기에 시행받도록 하여 양측 인공와우이식 간 격을 짧게 하는 것이 청각장애 아동의 청각언어기억 발달에 긍정적인 영향을 미칠 것을 기대할 수 있겠다.

핵심어: 양측 인공와우이식, 아동, 인공와우이식 간격, 듣기 조건, 청각언어기억능력

\section{참고문헌}

고선희, 최경순, 황민아(2009). 읽기 폭 과제로 측정한 정상아동의 작업기억 발달. 언어청각장애연구, 14(3), 303-312.

김광해(2003). 등급별 국어교육용 어휘. 서울: 박이정.

김리석, 장윤석, 허승덕, 이영미(2007). 소아에서 양측 인공와우이식 4예. 대한이비인후과학회지, 50(3), 260-264.

김민범, 김환, 최재영(2013). 동시 및 순차적 양측 인공와우 이식술의 시간 및 비용 비교. 대한이비인후과학회지, 56(10), 627-631.

김영태, 홍경훈, 김경희, 장혜성, 이주연(2009). 수용·표현어휘력검사(REVT). 서울: 서울장애인종합복지관.

김유정, 노지민, 이종주, 홍수아, 임혜진, 박헌이, 정연훈(2015). 순차적 양측 인공와우 아동들의 일상생활에서의 기능적 듣기수행력. 대한이비인후과

학회지, 58(7),463-468.

이미영, 신지철, 김향희, 김리석(2009). 학령전 아동의 단음절 말지각 검사 개발. 대한이비인후과학회지, 52(4), 312-321.

이영미(2014). 인공와우이식 간격과 듣기조건에 따른 순차적 양측 인공와우 아동의 말지각. Communication Sciences \& Disorders, 19(4), 564-573.

이영미(2018). 순차적 양측 인공와우이식 청년의 기능적인 듣기 수행력. Communication Sciences \& Disorders, 23(4), 1111-1126.

이영미, 심현섭(2015). 양측 인공와우이식이 청각장애 아동의 말지각에 미치는 영향. 재활복지, 19(3), 175-193.

이영미, 심현섭(2018). 이중과제 패러다임에서의 듣기 조건에 따른 양측 인공와우이식 아동의 문장 판단하기 및 듣기 노력. Communication Sciences

\& Disorders, 23(3), 764-774.

장성진(2013). 학령 전 인공와우이식 아동의 범주 지식에 따른 의미적 단기기억. 대구대학교 대학원 석사학위논문.

조현용(2000). 한국어 어휘교육 연구. 서울: 박이정.

\section{ORCID}

이영미(https://orcid.org/0000-0003-1809-5944) 